\title{
MEDIA PEMBELAJARAN ULAR TANGGA BILANGAN UNTUK MENINGKATKAN KEMAMPUAN KOGNITIF ANAK USIA 5-6 TAHUN
}

\author{
Nola Sanda Rekysika ${ }^{1}$ Haryanto $^{2}$ \\ Universitas Negeri Yogyakarta
}

\begin{abstract}
The early childhood is an important and crucial period for every human. The cognitive of children is well developed towards the stimulation around them. The cognitive development coverage at 5-6 years old children consists of general knowledge and science and also mathematic. Therefore, it is common that when in Kindergarten, children are taught to read, to write, and to count (calistung). There are some enjoyable ways to develop students' ability of recognizing and understanding the concept of numbers, one of them can be conducted by using educative playing tool "snake and ladder". This pre-experimental research design aims to improve the ability of children in 5-6 years old in the understanding of the numerical skill concept through the numerical snake and ladder learning media. The subject of the research was 22 students with the range of age 5-6 years old. Almost all aspects were significantly improved with the average of deviation between pretest and posttest which was more than 5,5. With the pretest score which was almost prevalent (average $=12.25 ; S D=0.86$ ) and the posttest score which was significantly improved (average $=17.9 ; S D=1.74$ ).
\end{abstract}

Keyword: snake ladder game, number operation, cognitive children aged 5-6 years.

\begin{abstract}
Abstrak: Masa usia dini adalah masa penting dan krusial bagi setiap manusia. Kognitif anak berkembang pesat melalui rangsangan di sekitar mereka. Lingkup perkembangan kogntif pada anak usia 5-6 tahun terdiri dari pengetahuan umum dan sains serta matematika. Oleh sebab itu tidak jarang apabila di PAUD, anak sudah diajarkan membaca, menulis, dan berhitung (calistung). Ada berbagai cara dalam mengembangkan kemampuan mengenal dan memahami konsep angka dengan cara yang menyenangkan bagi anak, salah satunya dapat dilakukan dengan menggunakan alat permainan edukatif (APE) ular tangga. Penelitian pre-experimental design ini bertujuan untuk meningkatkan kemampuan anak usia 5-6 tahun dalam pemahaman konsep bilangan melalui media pembelajaran ular tangga bilangan. Subjek ujicoba pada penelitian ini adalah 22 anak yang berusia 5-6 tahun. Hampir semuanya mengalami peningkatan yang signifikan dengan rata-rata selisih antara pretest dan posttest lebih dari 5,5. Dengan nilai pretest yang hampir merata (rata-rata $=12.25$; $\mathrm{SD}=0.86$ ) dan nilai posttest yang meningkat signifikan (rata-rata=17.9; $\mathrm{SD}=1.74$ ).
\end{abstract}

Kata Kunci: permainan ular tangga, operasi bilangan, kognitif anak usia 5-6 tahun.

\section{PENDAHULUAN}

Masa usia dini merupakan masa krusial bagi pada kehidupan manusia. Usia dini sering disebut dengan usia emas (golden age) karena pada masa ini pertumbuhan otak anak berlangsung dengan kecepatan yang tinggi dan mencapai proporsi terbesarnya (Uce, 2015). Intervensi efektif yang diterapkan selama masa usia dini dapat memberikan manfaat jangka panjang pada perkembangan, termasuk pada perkembangan kognitif (Camilli, Vargas, Ryan, \& Barnett, 2010). Pada dasarnya, perkembangan kognitif merupakan suatu hal yang fundamental. Hal ini dikarenakan perkembangan

\footnotetext{
${ }^{1}$ Universitas Negeri Yogyakarta | Email: nolasanda74@gmail.com

2 Universitas Negeri Yogyakarta, Emai: haryan62@yahoo.co.id
} 
kognitif sendiri melibatkan peningkatan cakrawala anak akan rangsangan yang diperoleh dari lingkungan sekitar serta peningkatan kemampuan memahami simbol di dalam memanipulasi lingkungan (Hijriati, 2016).

Lingkup perkembangan kogntif pada anak usia 5-6 tahun terdiri dari pengetahuan umum dan sains serta matematika. Adapun matematika pada anak usia 3-6 tahun menurut Alpaslan \& Erden (2016) menekankan pada pentingnya pengenalan bilangan dan kemampuan untuk mengimprovisasi anak dalam mengenalkan bilangan. Kemampuan ini dapat dilihat dari kemampuan anak dalam mengenal konsep bilangan, menghitung pada batas tertentu bahkan mengenal penambahan dan pengurangan secara sederhana. Oleh sebab itu, kemampuan dasar matematika perlu dirangsang dan dikembangkan sejak dini (Hartini, 2012).

Kenyataannya saat ini, anak-anak yang tidak memiliki dasar angka di PAUD akan kurang beruntung dalam belajar angka di sekolah lanjutan (SD) dibandingkan dengan anak yang sudah memiliki pengalaman belajar angka di PAUD (Pendidikan Anak Usia Dini) (Chien et al., 2010). Oleh sebab itu tidak jarang apabila di PAUD, anak sudah diajarkan membaca, menulis, dan berhitung (calistung). Banyak guru PAUD menggunakan teknik hafalan dan latihan demi mengajarkan kemampuan membaca, menulis, dan berhitung (calistung) (Yuliyono, 2012). Padahal teknik tersebut hanya mengandalkan kemampuan hafalan abstrak, tanpa terkait dengan kehidupan terdekat anak. Igrea Anaknto (2012: 11) juga menyatakan bahwa jika calistung diajarkan seperti halnya orang dewasa belajar, besar kemungkinan hal itu berakibat fatal. Anak-anak dapat kehilangan gairah belajar karena menganggap pelajaran itu sangat sulit dan tidak menyenangkan.

Menurut Wu \& Lin (2016), pembelajaran matematika untuk anak usia dini seharusnya berbentuk kegiatan bermain yang memiliki sebuah alur, sehingga anak menjadi antusias dan aktif terlibat dalam proses kegiatan pembelajaran, pengalaman, pengamatan, mengkategorikan, dan mengekspresikan kemampuan anak sendiri sambil menerima orang lain dengan tujuan akhir untuk bisa memecahkan masalah dan pemahaman dasar anak. Khususnya dalam kemampuan mengenal konsep bilangan yang abstrak, maka diperlukan strategi pembelajaran yang melibatkan pengalaman mereka terhadap lingkungan sekitar. Terlebih, anak usia dini masih berada pada tahap berpikir konkrit, sehingga strategi yang digunakan guru seharusnya mempertimbangkan penggunaan benda konkrit, kemudian sedikit-demi sedikit dapat menggantinya dengan gambar, maupun simbol (Mononen, 2014).

Ada berbagai cara dalam mengembangkan kemampuan mengenal dan memahami konsep angka dengan cara yang menyenangkan bagi anak, salah satunya dapat dilakukan dengan menggunakan alat permainan edukatif (APE) ular tangga. Hasil penelitian oleh Nachiappan, Rahman, Andi, \& Zulkafaly (2014) menunjukkan bahwa penggunaan permainan ular tangga dapat meningkatkan perkembangan kognitif anak dengan kesulitan dalam belajar matematika. Melalui permainan ini guru dapat membuat proses belajar mengajar menjadi lebih efektif dan bermakna serta menjamin partisipasi penuh dari anak dalam kegiatan pembelajaran. Sejalan dengan hasil penelitian di atas, Saraswati \& Supriyanti (2016) mengungkapkan bahwa permainan ular tangga raksasa berhasil dalam menarik perhatian anakanak serta pembelajaran menggunakan media tersebut dinyatakan efektif dan aman bagi anak-anak.

Penelitian ini bertujuan untuk meningkatkan kemampuan anak usia 5-6 tahun dalam pemahaman konsep bilangan melalui media pembelajaran ular tangga 
bilangan. Hipotesis penelitian ini adalah bahwa media pembelajaran ular tangga bilangan dapat meningkatkan kemampuan anak dalam memahami konsep bilangan yang dapat dilihat dari peningkatan skor dari pretest ke postest.

\section{METODOLOGI PENELITIAN}

Penelitian ini merupakan penelitian kuantitatif dengan jenis eksperimen yang bertujuan untuk meningkatkan kemampuan anak usia 5-6 tahun dalam pemahaman konsep bilangan melalui media pembelajaran ular tangga bilangan. Subjek ujicoba efektifitas pada penelitian ini adalah 22 anak yang berusia 5-6 tahun.

Instrumen yang digunakan berupa lembar observasi anak untuk mencatat pengamatan yang terjadi saat implementasi media pembelajaran ular tangga di kelas. Lembar observasi berupa checklist, penilaian, dan catatatan penting dalam implementasi yang dilakukan oleh ahli. Hal-hal yang diobservasi adalah kemampuan anak dalam mengenal bilangan dan operasi bilangan yang termasuk berpikir logis, dan berpikir simbolik. Lembar observasi telah divalidasi oleh ahli dan reliabilitas instrumen menunjukkan angka 0.81 yang mengindikasikan instrumen masuk kategori baik.

Penelitian ini menggunakan tiga pertemuan, sudah termasuk pretest dan posttest. Anak melakukan kegiatan belajar menggunakan permainan ular tangga untuk belajar mengenal bilangan dan operasi bilangan. Pertemuan pertama dilakukan pengisian pretest berdasarkan observasi oleh ahli. Pada pertemuan ketiga dilakukan pengisian posttest untuk melihat perbedaan hasil dari keduanya.

Uji efeektifitas dalam penelitian ini menggunakan metode penelitian preexperimental design bentuk one-group pretest-post testdesign (Sugiyono, 2008:116) sebagai berikut:

\section{$\underline{\mathbf{O}_{1} \times \mathbf{O}_{2}}$}

Gambar 1. One Group Pretest Post Test Design

Keterangan :

$\mathbf{O 1}=$ nilai pretest (sebelum diberikan perlakuan)

$\mathbf{O 2}=$ nilaiposttest (setelah diberikan perlakuan)

\section{HASIL PENELITIAN DAN PEMBAHASAN}

Hasil dari penelitian pengembangan ini berupa media pembelajaran ular tangga yang dilengkapi dengan buku panduan pemakaian. Bisa dilihat di Tabel 1 merupakan hasil dari penerapan media pembelajaran ular tangga bilangan.

Berdasarkan pada data tabel 1., hamper semuanya mengalami peningkatan yang signifikan dengan ratarata selisih antara pretest dan posttest lebih dari 5,5. Dengan nilai pretest yang hampir merata (rata-rata $=12.25$; $\mathrm{SD}=0.86$ ) dan nilai posttest yang meningkat signifikan (rata-rata=17.9; $\mathrm{SD}=1.74)$.

Peningkatan yang signifikan banyak terjadi pada anak yang sebelumnya mendapatkan nilai pretest yang dibawah rata-rata, sedangkan anak yang memiliki nilai di atas rata-rata cenderung mengalami peningkatan yang tidak sebesar yang di bawah rata-rata. Bahkan anak dengan nilai pretest tertinggi mengalami penurunan nilai. Hal ini menandakan bahwa media pembelajaran ular tangga untuk belajar mengenal bilangan dan operasi bilangan berdampak maksimal untuk anak dengan masalah kognitif berkaitan dengan bilangan sebelumnya. 
Tabel 1 Hasil Uji Efektivitas dengan Uji Wilcoxon

\begin{tabular}{|c|c|c|c|c|c|c|c|c|c|c|c|c|c|c|c|c|c|c|c|c|c|c|}
\hline $\begin{array}{c}\text { Kode } \\
\text { Anak }\end{array}$ & 1 & 2 & 3 & 4 & 5 & 6 & 7 & 8 & 9 & 10 & 11 & 12 & 13 & 14 & 15 & 16 & 17 & 18 & 19 & 20 & 21 & 22 \\
\hline Sebelum & 12 & 12 & 12 & 13 & 12 & 14 & 13 & 13 & 12 & 12 & 12 & 12 & 12 & 12 & 11 & 13 & 11 & 12 & 12 & 13 & 11 & 10 \\
\hline Sesudah & 16 & 18 & 19 & 16 & 20 & 13 & 20 & 18 & 17 & 17 & 18 & 20 & 20 & 20 & 17 & 17 & 17 & 19 & 17 & 19 & 19 & 17 \\
\hline Selisih & 4 & 6 & 7 & 3 & 8 & -1 & 7 & 5 & 5 & 5 & 6 & 8 & 8 & 8 & 6 & 4 & 6 & 7 & 5 & 6 & 8 & 7 \\
\hline Peringkat & 3,5 & 11 & 15,5 & 2 & 20 & 1 & 15,5 & 6,5 & 6,5 & 6,5 & 11 & 20 & 20 & 20 & 11 & 3,5 & 11 & 15,5 & 6,5 & 11 & 20 & 15,5 \\
\hline Positif & 5 & 111 & 15,5 & 2 & 20 & - & 15,5 & 6,5 & 6,5 & 6,5 & 11 & 20 & 20 & 20 & 11 & 3,5 & 11 & 15,5 & 6,5 & 11 & 20 & 15,5 \\
\hline J+ & 252 & & & & & & & & & & & & & & & & & & & & \\
\hline Negatif & - & - & - & - & - & 1 & - & - & - & - & - & - & - & - & - & - & - & - & - & - & - & - \\
\hline J- & 1 & & & & & & & & & & & & & & & & & & & & \\
\hline
\end{tabular}

Hasil penelitian ini didukung oleh penelitian yang dilakukan oleh Wing \& Tacon (2007) bahwa belajar mengenal bilangan akan lebih cepat dipahami apabila kegiatan belajar anak melibatkan pengalaman langsung dan melibatkan sensori anak, salah satunya dengan melibatkan media pembelajaran. Ketika anak bermain ular tangga, mereka akan membangun kreativitas dan aktivitas dalam belajar (Puspita \& Surya, 2017). Selanjutnya penelitian dari Baiquni (2016) menyimpulkan bahwa permainan ular tangga berpengaruh secara signifikan terhadap hasil belajar matematika. Secara khusus, Dewi, Purwanti \& Astuti (2014) juga menyebutkan bahwa permainan ular tangga dapat meningkatkan kemampuan anak dalam memahami konsep bilangan 1-10. Di sisi lain, penelitian dari Shitiq \& Mahmud (2010) menyimpulkan bahwa permainan ular tangga secara interaktif dapat membangkitkan motivasi dan minat belajar anak, dengan hasil penelitiannya yang meningkat secara signifikan. Oleh karena itu, dapat dimungkinkan apabila peningkatan yang signifikan terjadi karena anak lebih termotivasi di saat belajar mengenal bilangan dan operasi bilangan ketika menggunakan permainan ular tangga.

Berdasarkan hasil penelitian diperoleh bahwa anak dengan nilai pretest tertinggi justru mengalami penurunan pada nilai posttest. Hal ini bisa saja terjadi karena anak telah mengenal bilangan dan operasinya sebelumnya. Oleh karena itu, anak menjadi kurang termotivasi dalam belajar menggunakan permainan ular tangga ini, sehingga nilainya justru menurun. Temuan ini sama halnya dengan penelitian yang dilakukan oleh Barreto, Vasconcelos, \& Orey (2017) yang menyebutkan bahwa ada kalanya permainan tidak berdampak positif pada anak karena mereka tidak tertarik untuk memainkannya.

Selanjutnya akan dijelaskan kenapa penggunaan permainan dalam pembelajaran dapat memicu peningkatan kognitif anak. Hal ini tentu karena faktorfaktor dalam permainan yang dapat meningkatkan motivasi belajar anak. Permainan yang menarik, akan memikat anak untuk lebih giat dalam belajar. Permainan yang konten materinya disusun secara hati-hati dan teliti disesuaikan dengan tingkat perkembangan anak, maka tentu akan mempermudah anak dalam memahami suatu materi. Permainan ular tangga adalah permainan yang sederhana dan hampir setiap anak pernah memainkannya, sehingga anak mudah mengenali dan belajar menggunakannya. Hal ini merupakan salah satu faktor penting mengapa permainan ular tangga ini dapat meningkatkan kemampuan 
kognitif anak dalam mengenal bilangan dan operasinya.

Keterbatasan dari penelitian ini adalah penelitian ini hanya dilakukan dalam waktu tiga hari saja. Oleh karena itu, mungkin hasilnya akan berbeda jika dilakukan dalam jangka panjang. Materi yang diajarkan juga hanya pada mengenal bilangan dan operasinya saja, sehingga perlu dilakukan penelitian yang lebih lanjut untuk dampak pada materi yang lainnya.

\section{KESIMPULAN}

Penelitian ini menggunakan permainan ular tangga untuk belajar mengenal angka dan operasi bilangannya. Hasil dari penelitian ini menunjukkan adalah terjadinya peningkatan yang signifikan antara pretest dan posttest. Perubahan yang signifikan kebanyakan terjadi pada anak dengan masalah kognitif sebelumnya. Desain permainan yang menarik dan sederhana tidak membutuhkan keterampilan khusus untuk memainkannya, dapat dimainkan secara bersama-sama, dan materi yang disesuaikan dengan tingkat perkembangan kognitif anak menjadi faktor utama kenaikan pemahaman anak. Akan tetapi, dengan antusiasnya respon anak akan penggunaan media permainan ini bisa saja membuat anak menjadi kurang tertarik untuk belajar materi lain dengan cara yang biasanya kembali.

Terlebih lagi, implementasi pada penelitian ini hanya dilakukan dalam waktu tiga hari saja, sehingga perlu kajian lebih lanjut apakah perubahan ini berlanjut apa tidak. Subjek penelitian ini juga hanya pada beberapa sekolah di wilayah Yogyakarta, sehingga perlu kajian lebih lanjut apakah dapat digeneralisasi secara global.

Untuk memahami efektifitas permainan ular tangga ini lebih lanjut, rencana penelitian yang lebih lanjut adalah bagaimana efektifitas penggunaan permainan ini jika dilakukan dalam jangka waktu yang panjang, apakah masih konstan naik apa tidak. Selanjutnya juga akan diselidiki pengaruhnya pada faktor afektif, misalnya keterkaitan kenaikan pemahaman anak apakah dikarenakan motivasinya juga meningkat.

\section{DAFTAR PUSTAKA}

Alpaslan, Z. G., \& Erden, F. T. (2016). The status of early childhood mathematics education research in the last decade. Proceedings of the Ninth Congress of the European Society for Research in Mathematics Education, 1933-1939.

Baiquni, I. (2016). Penggunaan media ular tangga terhadap hasil belajar metematika. Jurnal Pengabdian Kepada Masyarakat, 01 (02), 193203.

Barreto, D., Vasconcelos, L., \& Orey, M. (2017). Motivation and learning engagement through playing math video games. Malaysian Journal of Learning and Instruction, 14(2), 121.

Camilli, G., Vargas, S., Ryan, S., \& Barnett, W. S. (2010). Meta-analysis of the effects of early education interventions on cognitive and social development. Teachers College Record, 112(3), 579-620.

Chien, N. C., Howes, C., Burchinal, M., Pianta, R. C., Ritchie, S., Bryant, D. M., ... Barbarin, O. A. (2010). Children's classroom engagement and school readiness gains in prekindergarten. Child Development, 81(5), 1534-1549.

Dewi, F. L., Purwanti., \& Astuti, I. (2014). Peningkatan kemampuan mengenal konsep bilangan melalui permainan ular tangga anak usia 4-5 tahun. Jurnal Pendidikan dan Pembelajaran, 3 (10), 1-14.

Hartini, P. (2012). Peningkatan kemampuan matematika anak melalui media permainan memancing angka di Taman Kanakkanak Fathimah Bukareh Agam. Jurnal Pesona PAUD, I(1). 
Hijriati. (2016). Tahapan perkembangan kognitif pada masa early childhood. Bunayya: Jurnal Pendidikan Anak, 1(2), 33-49.

Mononen, R. (2014). Early mathematics interventions: Supporting young children with low performance in mathematics. Helsinki.

Nachiappan, S., Rahman, N. A., Andi, H., \& Zulkafaly, F. M. (2014). Snake and ladder games in cognition development on students with learning difficulties. Review of Arts and Humanities, 3(2), 217-229.

Puspita, D. M., \& Surya, E. (2017). Development of Snake-Ladder game as a medium of mathematics learning for the fourth-grade students of primary school. International Journal of Science: Basic and Applied Research, 33 (3), 291-300.

Saraswati, M. A., \& Supriyanti, N. (2016). Developing the giant speaking snake and ladders board game for the teaching of speaking to children Aged 9-11. English Language Teaching Journal, 5(1), 9-12.

Anaknto Igrea \& Sri Lestari. (2012). Pembelajaran Atraktif dan 100 Permainan Kreatif untuk Anak Usia Dini.: Yogyakarta.

Shitiq, H.A.A.H., \& Mahmud, R. (2010). Using an edutainment approach of a snake and ladder game for teaching Jawi Script. International Conference on Education and Management Technology, 228-232.

Uce, L. (2015). The golden age: Masa efektif merancang kualitas anak. Bunayya: Jurnal Pendidikan Anak, 1(2), 77-92.

Wing, T., \& Tacon, R. (2007). Teaching number skills and concepts with Numicon materials. Down Syndrome Research and Practice, 12 (1), 22-26.

$\mathrm{Wu}$, S., \& Lin, F. (2016). Inquiry-Based Mathematics Curriculum Design for Young Children-Teaching Experiment and Reflection, 12(4), 843-860. https://doi.org/10.12973/eurasia.201 6.1233a.

Yuliyono. (2012). Dipaksa calistung saat paud, anak bisa jadi tak suka baca saat besar. GoodreadsIndonesiadiscussion. [Online]. Tersedia. 